\title{
"AL-MUSAQAH" AND SHARIA AGRIBUSINESS SYSTEM: An Alternative Way to Meet Staple Food Self- Sufficiency in Contemporary Indonesia
}

\section{Ujang Maman}

Universitas Islam Negeri (UIN) Syarif Hidayatullah Jakarta Jl. Ir. H. DJuanda No.95, Ciputat, Kota Tangerang Selatan, Banten Email: ujang.maman@uinjkt.ac.id

\section{Kusmana}

Universitas Islam Negeri (UIN) Syarif Hidayatullah Jakarta Jl. Ir. H. DJuanda No.95, Ciputat, Kota Tangerang Selatan, Banten Email: kusmana@uinjkt.ac.id

\section{Dudi Supiandi}

Universitas Ibnu Khaldun Bogor

\author{
Jl. KH. Sholeh Iskandar KM.2, Kedung Badak, Kota Bogor \\ Email: dudi2407@gmail.com
}

\begin{abstract}
The concept of al-musāqah appears in Islamic history when Prophet Muhammad conquered the fertile farmland surrounding Khaibar, abandoned by Jews as the original owner of the land. The concept of al-musāqah also appears in fiqh deliberations, in which it is a partnership between tenants and land owners. By deepening literature, the concept of al-musāqah is part of sharia agribusiness system that could be an alternative partnerships and farmer institution in meeting staple food needs. The alternative concept is very necessary since Indonesia has been facing the issue of agricultural land conversion and difficulty to form sustainable food agriculture area (SFAA). For the implementation of al-musāqah, the Government should systematically form the SFAA on the state owned land, and estabilish its institution to manage SFAA in the central and regional level. Then, the SFAA management implement almusāqah partnership with farmer groups. By the concept, the Government would be able to control staple food procurement and distribution to achieve food self-sufficiency which is profitable for farmers and non-farmers. However, the implementation is based on the view that the provision of basic needs should not be left to market mechanism.
\end{abstract}




\begin{abstract}
Abstrak. Konsep al-musāqah muncul dalam sejarah Islam ketika Nabi Muhammad menaklukkan lahan pertanian subur seputar Khaibar, yang ditinggalkan Yahudi sebagai pemilik asal lahan tersebut. Konsep al-musāqah juga terdapat dalam pembahasan fiqh, di mana konsep itu merupakan pola kemitraan antara petani penggarap dengan pemilik lahan. Melalui pendalaman pustaka, almusāqah merupakan bagian dari system agribisnis syariah yang dapat menjadi alternatif kemitraan dan kelembagaan petani dalam mencukupi kebutuhan pangan pokok. Konsep alternatif tersebut sangat diperlukan karena Indonesia sedang menghadapi persoalan konversi lahan pertanian pangan dan kesulitan membentuk Kawasan Pertanian Pangan Berkelanjutan (KPPB). Untuk mengimplementasikan konsep al-musāqah , Pemerintah secara sistematis harus membentuk KPBB pada lahan milik Negara dan membentuk institusi untuk mengelola KPPB di tingkat pusat maupun daerah. Kemudian, manajmen KPPB melaksanakan kemitraan al-musaaqoh dengan kelompok tani. Melalui konsep ini, Pemerintah dapat mengontrol pengadaan dan distribusi pangan pokok untuk meraih swasembada pangan yang menguntungkan bagi petani dan non-petani. Hanya saja penerapan konsep ini dengan asumsi bahwa pengadaan dan distribusi pangan pokok tidak diserahkan pada mekanisme pasar melainkan dikontrol secara ketat oleh Pemerintah.
\end{abstract}

Keyword: Basic Need, SFAA, State Owned Land, and al-musāqah

DOI: http://dx.doi.org/10.24239/jsi.v14i2.448.189-231

\title{
Introduction
}

There is a concept of al-musāqah in the fiqh study, ${ }_{1}^{1}$ which is literally taken from the word "as-Sakyu" that means flush. In a broader sense, al-musāqah is not just watering plants but managing or taking care the plants. More broadly, in terminological meaning, with refer to the explanation of Sayyid Sabiq, ${ }^{2}$ al-musāqah is a partnership pattern between the owners of agricultural land and tenant farmers where farmers cultivate the

\footnotetext{
${ }^{1}$ See for example Zainuddin Al-Malebary, Fath Al-Mu'în Bi Syarh Qurrah Al-'Ain, n.d., 82-83 This book is one of classical book (kitab kuning) which become one of the references for the santri (student of pesantren) in Indonesian Pondok Pesantren.

${ }^{2}$ Sayyid Sabiq, Fiqh Sunnah, Indonesian. (Bandung: Pustaka, 1993), 165.
} 
land to make it productive, ranging from preparing the land, planting, managing crops and harvesting, with all costs and means of agricultural production comes from land owners, while farmers only exertion with all the skills. By their work, the tenant farmers are entitled to part of the agricultural production with a certain ratio according to the agreement between the tenant and land owner, such as 50:50; 40:60; 60:40, and so forth.

Based on the generality of the meaning of al-musāqah, the land owner also can be an individual, or a number of people together as owners of the land, then also together do a partnership with the tennat farmers. The land owner can organize themselves in an organization or institution, either formally or informally. In addition, based on the events of Khaibar at the time of the Prophet Muhammad, ${ }^{3}$ the land owner may also a state. Therefore, in this context, the al-musāqah is a partnership pattern among organized land owners with the the tenant farmers. In addition, al-musāqah is also a partnership between the state - which can be represented by a particular institution - with the tenants farmers.

In line with this, the tennat farmers can be either an individual or a number of individual farmers which are organized in a farmer groups or other groups, both formal and informal group. If the farmers are not individual, then al-musāqah is a partnership pattern between the Government or companies (in which the owner is composed of a number of individuals) with farmer groups to manage state-owned land or private land to make the land productive. Referring to the events of Khaibar, the entire cost of the production comes from The Prophet Muhammad as head of state or can also come from the land owner for the private land owner; while farmers or farmer groups are just as tenants with

\footnotetext{
${ }^{3}$ After the conquest of Khaibar, Fadaq dan Wadil Qurro, there is a land that becomes the right of the Prophet Muhammad SAW as a head of state. The land actually is the state owned land which is managed by Jews as the previous inhabitants of Khaibar, Fadaq, and Wadil Qurro based on the agreement of profit sharing with the Prophet Muhammad. See: Abū Muhammad Abū al-Mālik alMuafirī Ibn Hisyam, Sïrah Nabawiyyah Ibn Hisyām (Jakarta: Darul Falah, 2003), 321-325. See also Syaikh Syafiyyah al-Raḥmān al-Mubārak Fūrī, Al-Rahị̄q AlMakhtūm (Riyadh: Muassasah al-Ṡaqāfah, 2012), 317.
} 
certain revenue sharing. ${ }^{4}$ In the context of contemporary Indonesia, it is expected to be able to formulate an alternative institutional pattern of partnership between farmers and government based on al-musāqah, in which the article aims to to formulate an alternative farmers institution.

The existence of alternative of farmer institution system and a partnership pattern is very important by several reasons. First, there has been at wetland conversion massively in Indonesia during the past 20 years; and this is a serious threat to the staple food self-sufficiency and national food security. Second, in Indonesia there has been an extraordinary pressure on agricultural land due to the population growth which needs housing; dynamics of development that requires infrastructure extension; the dynamic of government institution that requires the encrease of the offices complex and other facilities. Thirdly, the Government of Indonesia by referring to Law No. 41/2009 has been trying to form Sustainable Food Agriculture Area (SFAA) by providing strict sanctions (in the form a of imprisonment or fines) to farmers who dare to undertake the conversion of agricultural land that are designated as SFAA. But it turns out that the establishment of the SFAA is not effective even pose a potential economic losses for farmers. Fourth, the Government effort to make a new paddy fields does not have the clarity of ownership and the institution as the owner, something that can lead to the agrarian conflict in the future. Fifth, the farmers gradually are no longer interested in working on agricultural land due to the small revenue of the agricultural sector, the low social status of farmers, and risky for incursion of pests and diseases.

The various issues must be resolved, because the need for food is not inevitable. Indonesia should immediately achieve the food self-sufficiency, or at least Indonesia should be on the right track, which achieves a food self-sufficiency in the certain period appropriate with a systematical planning. The food availability is part of human right which has to be achieved and could not be

${ }^{4}$ Sabiq, Fiqh Sunnah, 166. 
postponed. In this context, there is a challenge for the Islamic studies to contribute to solve the issue of food scarcity. Therefore, the formulation of partnership pattern between Government and farmers and the formulation of farmer institutional system is part of Islamic studies based on the empirical as well as the normative facts which are expected to contribute comprehensively to solve this human right issue. This also is expected to get a new way in the Islamic studies in the field of farmer's institutional system and partnership pattern in farming business development.

To study about al-musāqah and its implementation to meet the staple food needs the normative studies, especially about the understanding of the al-musāqah concept and the context of its birth in the Islamic history. The study needs also the factual comprehension about various issues of food agricultural in Indonesia, at least about wetland conversion, dynamic effort to solve the issues and its difficulties, especially the problem which related to the government effort to form the SFAA. Therefore, the process of this study is divided into two parts. First, analysis of major issues toward food self-sufficiency which included: (a) the dynamic of land conversion, (b) the attributes for Indonesia from FAO as a food insecure state due to rapid paddy land conversion; and (c) unfortunately the Government gets difficulty to form SFAA mandated by the law No. 41/2009 about the protection of sustainable food agricultural land (P-SFAL). Finally, as the second part, the study presents the expected solution by sharia agribusiness system approach - in which the almusāqah is an integrated part of the system - toward food selfsufficiency.

\section{Method of Study}

In reviewing the history of Islam on al-musāqah and its normative discussion, as well as in-depth studies on various agricultural issues, this research is literature study. Referring to Neuman, the research uses a content analysis. It collects and analyzes contents of a text in the form of books, magazine articles, and official documents. The analysis emphasizes not only on the visible content of the document but the latent contents, in the form of ideas, thoughts, or the core that illustrates the connection of one 
idea to another indirectly. This study uses a quantitative logic, but the presentation and data analysis conducted qualitatively, without coding, numerical, and statistical tests. For Neuman as well as Kalof, the content analysis does not necessarily have to be quantitative. Instead, it uses a quantitative logical framework with qualitative way in presentation and data deepening. According to Neuman, analysis of documents in this way has an advantage, because it is non-reactive, no researchers influence in data collection that would interfere the objectivity of data. By the way of method, the research will produce more accurate data. ${ }^{5}$

Regarding the trends of qualitative in the content analysis actually has not been unusual, although it is considered odd in the light of positivistic research methodology. Holsti which is regarded as one of the founding stone of quantitative content analysis in his article in 1969 gave the green light for the qualitative in content analysis. Holsti stressed the need of interpretation, imagination, and intuition role in looking at the contents of a message; and it could not be done by purely quantitative. ${ }^{6}$ Therefore, for more details, the type of this study is theoretical-oriented content analysis, which is different from classical content analysis. Quoting Carney (1972), Muhajir asserts that theoretical oriented content analysis aims to make inferences, relationships, or pulls the core of latent contents of the text, with analyzing themes of a document, which is taken by purposive to achieve the objective of study. ${ }^{7}$

${ }^{5}$ Lawrence W. Neuman, Social Research Methods: Qualitative and Quantitative Approaches (Boston: Allyn and Bacon, 1994), 261-262. See also Kalof, et al., Essential of Social Research (New York: Open University Press, 2008), 105

${ }^{6}$ Ole R. Holsti, Content Analysis for The Social Sciences and Humanity (Califonia: Addison-Wesley Publishing Company, 1969), 12-13.

${ }^{7}$ Noeng Muhajir, Metodologi Penelitian Kualitatif (Yogyakarta: Rake Sarasin, 2000), 69-70. 
Ujang Maman, et al., "Al-Musāqah" And Sharia Agribusiness System...

The Major Issues toward Staple Food Self-Sufficiency in Indonesia The Massive Agricultural Wetland Conversion

The typology of rice agricultural farming structure in Southeast Asia, particularly in Indonesia, is a family based farming. Referring to Kuhren and Mubyarto, Rahardjo recognizes that Indonesian agri-food is a family farming, in which it is attributed by narrow land area, farming to meet the family needs, as well as food crops such as rice and secondary crops become the main activities that are often supported by vegetables and livestock in small scale. ${ }^{8}$ The study of Fujimoto, ${ }^{9}$ Neef, ${ }^{10}$ and Nabangchang and Srisawalak ${ }^{11}$ with a variety of viewpoints and diverse problems, affirmed the thesis that the agri-food in Southeast Asia, especially in Indonesia, is a family farm.

The Fujimoto's research in Ranca Ekek (Bandung) and Ranca Udik (Subang) found that family-based rice farming in the late 1990s was still quite dominant. From 98 families who live in Ranca Udik, about 59 people (60.20\%) were family farmers with average land farm area about 0.64 ha in Ranca Udik. Unlike Ranca Udik which is an agricultural village, Ranca Ekek that close to urban areas, from 93 families in the location, only 10 families (10.7\%) were

\footnotetext{
${ }^{8}$ Rahardjo, Pengantar Sosiologi Pedesaan Dan Pertanian (Yogyakarta: Gadjah Mada University Press, 1999), 134.

${ }^{9}$ Akmi Fujimoto, "Rice Land Ownership And Tenacy System in South East Asia: Facts and Issues Based on The Village Studies," The Developing Economies XXQUOTEDXI, no. 3 September (1996).

${ }^{10}$ Andreas Neef, "Land Tenure and Soil Conservation Practices: Evidence from South Africa and South East Asia," in Sustaining the Global Farm (Selected Paper from the 10th International Soil Conservation Organization Meeting, ed. D.E. Stott, R.H. Mohtar, and G.C. Steindhardt (Purdue University and USDA-ARS National Soil Erosion Research Laboratory, 1999) held May, 24-29, 1999.

${ }^{11}$ Orapan Nabangchang and Eathipol Srisawalak, Good Governance And Natural Resources Tenure In South East Asia Region (Rome: Food And Agriculture Organization Of The United Nations, 2008).
} 
in the category of family farmers with an average land area of 0.44 ha. ${ }^{12}$

The 2003 and 2013 agricultural census (AC) data also illustrated the dominance of family farms as Indonesian food producers. In 2003 there were at least 14206 thousand rice farmer family; and in 2013 was reduced to 14147 thousand farmers. ${ }^{13}$ Referring to same source, the control of wetland size for each family in Indonesia is average of 0.69 ha. In more detail the size of land tenure in the Sumatra is about of $0.68 \mathrm{ha}$; in Java $0.61 \mathrm{ha}$; in Bali and Nusa Tenggara 0.72 ha; 0.78 ha in Kalimantan; in Sulawesi area of $1.32 \mathrm{ha}$; and in Maluku and Papua, an area is about 2.72ha. ${ }^{14}$ The land area is still too large compared to the invention of Susilowati and Maulana in which the control of paddy land in Java is about 0.36 ha. ${ }^{15}$

However, the Indonesian family-based rice farming most likely faces serious problems as a consequence of land conversion that takes place on a massive scale. Based on AC data by the Central Bureau of Statistics (CBS) during the period of 1983-1993 wetland conversion reached $1,280,268$ ha and mostly occur in Java. Whereas during the period of 1993-2003 amounted to 1,284,109 ha agricultural land conversion took place, mostly occurred in Sumatra, as for more detail presented in Table 1.

In the span of time, throughout the Indonesian major islands, such as Java, Nusa Tenggara, Sumatra, Kalimantan, Maluku, and Papua, there is a significant decline of food agri-land area. In the

\footnotetext{
${ }^{12}$ Fujimoto, "Rice Land Ownership And Tenacy System in South East Asia: Facts and Issues Based on The Village Studies," 288.

${ }^{13}$ National Development Planning Board, Analysis of Household, Land, and Agribusiness in Indonesia: Agricultural Census 2013 (Jakarta: NDPB, 2014), 21.

${ }^{14}$ Ibid., 51

${ }^{15}$ Sri Hery Susilowati and Mohamad Maulana, "Luas Lahan Usahatani Dan Kesejahteraan Petani: Eksistensi Petani Gurem Dan Urgensi Kebijakan Reforma Agraria," Analisis Kebijakan Pertanian 10, no. 1 (2012): 1.
} 
span of 30 years there is indeed the increasing number of paddy fields. However, the addition of agri-land was not significant compared to the loss of rice field. In Sulawesi, during the period 1983-1993 there was an increase of 134693 ha paddy-fields; in Maluku area of $21717 \mathrm{ha}$; and in Irian Jaya area of $9455 \mathrm{ha}$. Similarly, for the period 1993-2003 there was an addition of rice field area. In Bali and Nusa Tenggara there were addition of 35333 ha land area, and there was land addition in Sulawesi covering 412 064 agricultural land area; but the increase was insignificant compared to the amount of rice field lost during 1993-2003 period which covered of 1,284,109 ha land area throughout Indonesia.

The amount of converted paddy fields is more alarming if refer to the results of the 2013 and 2012 AC. According to the Agricultural Statistics of NDPB, the Indonesian rice field based on the 2013 AC was covering of 8685 888ha; while the rice paddy field area in the 2012 according to the Ministry of Agriculture (MoA) was amounted of 8,132,345 ha, which consisted of technical irrigation rice area of 4,417,581and non-technical irrigation rice field of 3,714,763ha. According to the MoA, the data is the result of agreement between MoA and the National Land Agency. ${ }^{16}$ Therefore, in the period of ten years, from 2003 to 2013, there had been a shrinking amount of paddy fields which was is not less than 5454006 ha. Throughout the major Indonesian islands, such as Sumatra, Kalimantan, Sulawesi, Bali, Maluku and Papua acreage of rice decreased significantly, ${ }^{17}$ as presented in Table 1 . Even more, referring to $1983 \mathrm{AC}$ data, which was within a span of 30 years is calculated, Indonesia has lost 8,013,384 ha paddy field or of 267279 ha area per year.

\footnotetext{
${ }^{16}$ Center for Agricultural Data and Information System, Statistics of Agricultural Land 2008-2012 (Jakarta: MoA, 2013), 5.

${ }^{17}$ National Development Planning Board, Analysis of Household, Land, and Agribusiness in Indonesia: Agricultural Census 2013, 53.
} 
Vol. 14, Number 2, December 2017: 189-231

Table 1. The Existed Paddy Agricultural Land in Indonesia, 1983-2013

\begin{tabular}{lrrrr}
\hline \multicolumn{1}{c}{ Regions } & \multicolumn{4}{c}{ Agricultural Census Data } \\
\hline & AC 1983* & AC 1993** & AC 2003*** & AC 2013**** \\
Java & 5422449 & 4407029 & 4019887 & 4790016,8 \\
Bali \& NT & 1208164 & 1060218 & 1095551 & 499326,4 \\
Sumatera & 5668811 & 5416601 & 4249706 & 1724256,9 \\
Sulawesi & 1637811 & 1772444 & 2184508 & 1088382,2 \\
Kalimantan & 2222153 & 2191596 & 2096230 & 526670,5 \\
Maluku \& Papua & 544984 & 576116 & 494013 & 57238,7 \\
Indonesia & 16704272 & 15424004 & 14139895 & 8685888,7 \\
\hline
\end{tabular}

Source: $\quad$ *AC, CBS 1983 (Quoted from Beranda Inovasi.com, March 4, 2013)

**AC, CBS 1993 (Quoted from Beranda Inovasi.com, March 4, 2013)

***AC, CBS 2003 (Quoted from Beranda Inovasi.com, March 4, 2013)

**** AC, CBS 2013 (Quoted from NDPB, 2014)

For more detail in several Indonesian regions the land conversion continuously occurred. As an illustration, with refer to the research of Barokah et al, ${ }^{18}$ during a period of 12 years (1998 to 2010) in Karanganyar Region, the conversion of wetland area consumed 0.283 ha $(283 \mathrm{~m} 2)$ per farmer households in the district of Jaten and 0.053 ha $(53 \mathrm{~m} 2)$ in District Jumantono. Both are in Karanganyar, Central Java. In 1998, in Karanganyar, the average of paddy land ownership was still on 0.3 ha but in 2010 dropped only to 0,296 ha.

In the other regions, there has been the same trend of land conversion. The thesis research in Universitas Dipenogoro conducted by Handari in Magelang, Central Java, showed within a period of six years, from 2005 to 2011 there was a trend of paddy farmland decline. In 2005 wetland area in Magelang District was recorded of 37445 ha and shrank to 37219 ha in 2011. According to Handari, the tendency of land conversion continues. It is based on the obtained data from Magelang District Land Office regarding the filing of agricultural land use change permits, namely in the year 2010 as many as 47, in 2011 were 22 and in 2012 as many as 15 filing. It does not include the land conversion without going through the

\footnotetext{
${ }^{18}$ Ummu Barakah, et al., Dampak Konversi Lahan Pertanian Terhadap Pendapatan Rumah Tangga Petani Di Kabupaten Karanganyar (Solo, 2012), 4-5. Executive summary of the research.
} 
official licensing procedures. ${ }^{19}$ The Apriyana's observation shows that there will be the large scale conversion of food-agri land in some areas of Java, both the close and relatively far area to the capital. Two areas close to the capital, namely Cianjur and Tangerang, the both have a tendency of paddy farmland decline. The area which is far from the capital is Mojokerto, also has the same tendency, the occurrence of paddy farmland conversion. ${ }^{20}$

\section{The Food Insecure State}

In the middle of food farmland shrinkage, the need of food consumption, especially of rice, continued to increase in line with population growth. Rice consumption in Indonesia is the highest in the world, at an average $139 \mathrm{~kg}$ of rice per capita per year, higher than Philippines who spent $131 \mathrm{~kg}$ of rice per year. Whereas the average world rice consumption is only $60 \mathrm{~kg}$ per capita per year. ${ }^{21}$ In 2013, the number of Indonesia's population is 230 million people. That is, for 2013 itself, Indonesia needs at least 31.97 million tons of rice. And to produce rice as much as its number, requires 12 million ha of land. By 2015 itself, with population of 255 million people, Indonesia needs 13.38 million ha of rice fields.

Therefore, according to the MoA, in a few years, Indonesia will experience a deficit of agricultural land area of 730,000 ha. If it is left untreated, the land deficit will increase to 2.21 million ha in 2020. And the trend will continue to grow to 5.38 million ha in 2030 if no measured treatment is introduced. ${ }^{22}$ Furthermore, if following

\footnotetext{
${ }^{19}$ M.F. Anita Widhy Handari, "Implementasi Kebijakan Lahan Pertanian Pangan Berkelanjutan Di Kabupaten Magelang." (Universitas Diponegoro Semarang, 2012), 4-5.

${ }^{20}$ Nana Apriyana, Kebijakan Pengendalian Konversi Lahan Pertanian Dalam Rangka Mempertahankan Ketahanan Pangan Nasional (Jakarta: Kementerian Perencanaan Pembangunan, 2011), 11-14.

${ }^{21}$ Kumara Jati, "Staple Food Balance Sheet, Coefficient of Variation, and Price Disparity in Indonesia," Journal of Advanced Management Science 2, no. 1 March (2014): 65-66.

${ }^{22}$ Berdikari Online, 23/2/2013
} 
the $2013 \mathrm{AC}$ data presented by NDPB, ${ }^{23}$ in 2015 Indonesia has been a shortage of about 4 million ha of farm land from the size of land required according to the MoA in 2015, which is about 13.38 ha.

Whereas, Indonesia between 1995-2000 has not actually been successful to meet some needs of major food, such as rice, corn, sugar, vegetables, fruit, beef, poultry, milk, and eggs. According to the FAO report in Food Balance Sheet, ${ }^{24}$ in 2000 Indonesia's stock of rice was minus $3.8 \%$ of the total requirement; corn minus $11.8 \%$; sugar minus $46.5 \%$; vegetable minus $4.8 \%$; fruit minus $3.9 \%$; cow minus $8.3 \%$; poultry minus $2.0 \%$; and milk minus $75.4 \%$. The shortages of staple foods have not yet been fully resolved until 2011. In that year, several Indonesia's provinces still got a shortage of rice, such as NTT (minus 320 tons), Papua (minus 329 tons), Banten (minus 386 tons) and Riau (minus 380 tons). In addition, in 2011 several Indonesia's provinces are still lack of corn, soybeans and sugar. For corn, Riau was still lack of 254 tons, South Sumatra minus 245 tons, Jakarta minus 480 tons, Banten minus 521 tons, and West Java minus 1491 tons. For soybeans, Indonesia is still dependent on import, with a total lack of $1,280,357$ tons. For sugar, Indonesia still lacks of 1,059 tons. ${ }^{25}$

Based on the food condition, in 2014 FAO, IFAD (International Fund for Agricultural Development), and WFP (World Food Program) classified Indonesia as a food insecurity state, in line with Brazil, Haiti, Madagascar, Malawi and Yemen, with the indicator is the level of difficulty to obtain food for individuals and families, although the three international institutions appreciated Indonesia's efforts to meet the needs of food independently and reduce the problem of malnutrition. However FAO, IFAD and WFP provide important notes, that Indonesia has not get success to

\footnotetext{
${ }^{23}$ National Development Planning Board, Analysis of Household, Land, and Agribusiness in Indonesia: Agricultural Census 2013, 53.

${ }^{24}$ Quoted from Bayu Krisnamurthi, "Revitalisasi Pertanian: Sebuah Konsekuensi Sejarah dan Tuntutan Masa Depan," in Revitalisasi Pertanian dan Dialog Peradaban, ed. Bayu Krisnamurthi (Jakarta: Kompas, 2006), 15.

${ }^{25}$ Jati, "Staple Food Balance sheet, Coefficient of Variation, and Price Disparity in Indonesia," 66-67.
} 
control food agricultural land conversion though the Parliament and the Government has adopted a law to hold land conversion. ${ }^{26}$

\section{The Difficulties to Form Sustainable Food Agricultural Area}

In accordance with the notes of FAO, IFAD and WFP, the formation of SFAA is a necessity, and it is the right solution to control food agri-land conversion. Referring to FAO's principles of sustainable development, ${ }^{27} \mathrm{SFAA}$ has functions for natural resources protection, maintain eco-systems functions, strengthen resilience of economy, and to protect the ability of future generations to obtain food needs. This is in line with the principles of the World Commission on Environment and Development (WCED) which confirms that sustainable development economically is expected to increase human welfare; socially it is hoped to encourage equal achievement of society, and ecologically it is designed to control environmental risks and ecological scarcity. ${ }^{28}$

However, economically and culturally in Indonesia, the establishment of SFAA faces several problems. The issues of SFAA formation can be mapped into two major parts. First, the internal problems of farmers who experienced changes in their orientation and view point toward the land. Second, the issue of development dynamics that tends to suppress the farm land. The first issue, in fact the food agriculture land, especially paddy fields, is the farmer individual owned land with a size is about 0.36 ha per farmer household. ${ }^{29}$ Therefore, the formation of SFAA essentially is Government's request to the farmers to give up their paddy fields

\footnotetext{
${ }^{26}$ IFAD and WFP FAO, The State of Food Insecurity in the World: Strengthening the Enabling Environment for Food Security and Nutrition (Rome: FAO, 2014), 30-31.

${ }^{27}$ FAO, Sustainability Assessment of Food and Agriculture Systems (Rome: FAO, 2012), 12.

${ }^{28}$ Ibid., 1.

${ }^{29}$ Susilowati and Maulana, "Luas Lahan Usahatani Dan Kesejahteraan Petani: Eksistensi Petani Gurem Dan Urgensi Kebijakan Reforma Agraria,” 1.
} 
to serve as SFAA, to provide food for the society, either for the poor or rich; both for mediocre income or the industrialists who live well. When farmers exchange rate continued to fall compared to those who work in the industrial sector, the establishment of SFAA essentially makes farmers as a "subsidy giver" for the industrialists.

Suppose the SFAA formation in the middle of Indonesian subsistence-peasant, it probably will not be too difficult to define their land as SFAA; and farmers would be easy to accept. However, Rahardjo emphasized the tendency of commercial-capitalistic of their view on farmland is increasingly institutionalized in rural communities. ${ }^{30}$ The trend of changing actually has been going on since the 1980s or even earlier. In 1985 Garcia has described the spread of the money economy in rice production centers in the villages of Southeast Asia, including in Indonesia. Referring to the Smelser (1966), Garcia explained, subsistence activities have started decaying and replaced by market-oriented production. This has resulted in changing of labor relations, solidarity, and gotong-royong (mutual help) on subsistence farming community, namely the emergence of the hired workers. The rights and obligations which often appears traditionally at the time of harvest as a characteristic of subsistence farming community has faded, and replaced by a contractual relationship. ${ }^{31}$

The farmer's viewpoint of money-oriented is not only on agricultural products, but also affects their perspective on agricultural land. The Pradnyana's research in Tabanan, Bali, proved that most farmers have viewed agricultural land as an economic commodity that can be traded for profit, as presented in Table 2. For more detail, as much as $75 \%$ of the respondents strongly agree and agree that agricultural land is the economic

\footnotetext{
${ }^{30}$ Rahardjo, Pengantar Sosiologi Pedesaan Dan Pertanian, 190.

${ }^{31}$ Manuel B. Garcia, Sociology of Development: Perspective and Issues (Manila: National Book Store, 1985), 135.
} 
good. The research of Irawan et al (2000), revealed that about 70$90 \%$ of farmers in Subang and Indramayu district who sold farm land, they allocated about 50-60\% of the earned money to buy back the rice fields; and they allocated less than $5 \%$ of the money for investments outside the agricultural sector. ${ }^{32}$ The research of Sumaryanto et al (2000) in West and East Java showed the same trend. Approximately 50-60 \% of farmers in these areas buy rice field back after selling his land to be converted by the other party. ${ }^{33}$

Table 2.The Farmer Orientation toward Agricultural Land ${ }^{34}$

\begin{tabular}{lllccccccc}
\hline \multirow{2}{*}{ No. Indicator } & \multicolumn{2}{c}{ SA } & \multicolumn{2}{c}{ A } & \multicolumn{2}{c}{ NA } & \multicolumn{2}{c}{ SNA } \\
\cline { 2 - 9 } & Res & $\%$ & Res & $\%$ & Res & $\%$ & Res & $\%$ \\
\hline 1 & $\begin{array}{l}\text { Land conversion is able to solve } \\
\text { the economic problem }\end{array}$ & 17 & 15,18 & 68 & 60,71 & 25 & 22,32 & 1 & 1,79 \\
\hline 2 & $\begin{array}{l}\text { Agricultural land is an economic } \\
\text { commodity }\end{array}$ & 27 & 24,11 & 58 & 51,79 & 21 & 18,75 & 6 & 5,36 \\
\hline 3 & $\begin{array}{l}\text { Land could not afford to produce } \\
\text { expected yield }\end{array}$ & 9 & 8,04 & 86 & 76,79 & 16 & 14,29 & 1 & 0,89 \\
\hline 4 & $\begin{array}{l}\text { Land for housing is more } \\
\text { benefited }\end{array}$ & 16 & 4,29 & 60 & 53,57 & 31 & 27,68 & 5 & 4,46 \\
\hline
\end{tabular}

When the farmers are squeezed by economic problems because of the small income from rice farming, the heightened price of agricultural land because of its location which is increasingly strategic and became the target of investors bring "benefits" for their own to overcome economic problems without having to lose their land. But, generally, the number of the rest land area is constantly reduced, and growing a number of farmers who lost their land.

The farmers who have business, profit, and money oriented have to deal with the fact that the benefits they receive from the agricultural sector is very small. Krisnamurthi exposed the income

\footnotetext{
${ }^{32}$ Bambang Irawan, "Konversi Lahan Sawah: Potensi Dampak, Pola Pemanfaatannya, Dan Faktor Determinan," Forum Penelitian Agro Ekonomi 23, no. 1 (2005): 15.

${ }^{33}$ Quated From Ibid.

${ }^{34}$ This data is processed from I Made Mahadi Dwipradnyana, "FaktorFaktor Yang Mempengaruhi Konversi Lahan Pertanian Dan Pengaruhnya Bagi Kesejahteraan Petani: Studi Kasus Di Subak Jadi, Kediri, Tabanan" (Udayana University, 2014), 85.
} 
received by agricultural sector workers (ASW) in 1970s is not much different from the income received by industrial sector worker (ISW). However, within 30 years, the income received by ISW increased three-fold compared to the ASW; while the ASW received only a third of the ISW income. This trend, according Krisnamurti, is based on the fact that the agricultural sector's contribution to GDP declined from $70 \%$ in 1970 s to $30 \%$ in early 2000 s. Unfortunately, the decrease is not followed by a decrease in the number of workers who depend on the agricultural sector. ${ }^{35}$ In the span of 2004-2012 there was also the same trend. The agricultural sector's contribution to GDP is only around $14 \%$, whereas in the same period the number of workers who depend on the agricultural sector is about $35 \%{ }^{36}$ This is a strong indicator of ASW's income tendencies from of the 2000s to the present.

Based on the light of facts, working on paddy farmland has no appeal for farmers or landowners which are more rational, profit and business-oriented. More than $80 \%$ of sample- farmers in Pradnyana's research agree and strongly agree that paddyagricultural land is not able to provide an expected income (Table 2). If it is associated with farmers' earlier statement that the land is an economic commodity, they have a strong tendency to sell and convert the paddy field. Moreover, it is a fact that farmers who are converting their land get better income than those who consistently work on paddy-field. The research of Barokah et al proved that the paddy fields conversion causes the increasing of farmer income by Rp 2.291 million per year in District of Jaten and Rp 378,000 in District of Jumantono. Similarly, the outside farmingincome is also increasing. After converting the land, according to Barokah et al., the household's farmer income outside farming

\footnotetext{
${ }^{35}$ Krisnamurthi, "Revitalisasi Pertanian: Sebuah Konsekuensi Sejarah Dan Tuntutan Masa Depan," 11-12.

${ }^{36}$ National Development Planning Board, Analysis of Household, Land, and Agribusiness in Indonesia: Agricultural Census 2013, 10.
} 
earned Rp8.568 million per year in the District of Jaten and Rp 1.52 million per year in District of Jumantono. ${ }^{37}$

The Asmara's research on the farmers in Sub District of Mekarwangi, Bogor City, West Java showed the opportunities of better income for those who sell their paddy-land, either whole or part. By using the "Future Value Formula" to compare nominal income of farmer in the 2000s before converting paddy-land and the income in in 2010 after converting the land and apply a business in other sectors, it is about $50 \%$ of the sample farmers earn more income, and its increase is more than $100 \% .{ }^{38} \mathrm{By}$ referring to Witono and Nasution (1996), Irawan confirmed the probability of higher income for farmers who sell and convert their paddy-land by indicator of rental value ratio of farm and non-farm land. Thus, the different value of the rent for the housing complex, the ratio is 1: 622; for the industrial estate of 1:500; and 1:14 for the area of tourism. This comparison applied in 1996 when the study was conducted, ${ }^{39}$ and probability of increasing value for contemporary period.

In such conditions, farmers are dealing with the dynamics of development, with its interest to convert agricultural land, by rising of land price in constant increasing. Selling of agricultural land is often seen as a problem-solving. Pradnyana revealed, more than $80 \%$ of the farmers stated strongly agree and agree that land conversion is able to overcome the economic problems (Table 2). At the same time, more than $70 \%$ of the farmer stated strongly agree and agree that wet land conversion for housing brings more benefits for them (Table 2).

The formation of SFAA, in this context, has actually closed the farmers' opportunity to earn higher returns from job

\footnotetext{
${ }^{37}$ Barakah, Dampak Konversi Lahan Pertanian Terhadap Pendapatan Rumah Tangga Petani di Kabupaten Karanganyar, 4-5.

${ }^{38}$ Andi Asmara, "Pendapatan Petan Setelah Konversi Lahan: Studi Kasus Kelurahan Mekarwangi, Kota Bogor" (Universitas Islam Negeri Syarif Hidayatullah Jakarta, 2011), 78-79.

${ }^{39}$ Irawan, "Konversi Lahan Sawah: Potensi Dampak, Pola Pemanfaatannya, dan Faktor Determinan," 8.
} 
opportunities and land use in other sectors, particularly in the industrial sectors which are more profitable. Qualitative research conducted by Handari in Magelang District presenting statement of a farmer in local area of Krajan, Village of Trasan, Sub-District of Bandongan, that:

"If the paddy-field I had, and I was constantly make it as a rice field, I think al loss, the result is not much, a year is just only two time of harvests, the cost should I spend for it is a lot. But now my rice field I have made it a store, the results is so more, and also in the main road." 40

The disappearance of profit opportunities for farmers in SFAA formation has been disturbing the sense of justice for the farmers; and it greatly disturbs the smoothness of SFAA formation. In line with SFAA formation, the FAO created the SAFA (Sustainability Assessment of Food and Agriculture) indicators in agricultural development, in which it included people (social aspect), planet (environmental aspects), and profit (the economic aspect). ${ }^{41}$ It means that the formation of SFAA should benefit all parties, including farmers.

In relation to the establishment of SFAA, Indonesian Government actually has set up an incentive for farmers whose lands are set to be SFAA, as it is contained in Government Regulation (GR) No. 12/2012. According to Article 7 of GR 12/2012, the form of incentives are: property tax waiver; development of agricultural infrastructure; financing a research and development of seeds and varieties; ease access of information and technology for the farmer; the provision of agricultural inputs; the grant for the issuance of land certificates in SFAA; and/or rewards for high achievers farmers. By wide spreading of paddy-field conventions, the incentive is thought to have not been effective. The flow of land conversion is much higher than the incentives which are served as a retaining current flood of land conversion.

\footnotetext{
${ }^{40}$ Handari, “Implementasi Kebijakan Lahan Pertanian Pangan Berkelanjutan Di Kabupaten Magelang." 62.

${ }^{41} \mathrm{FAO}$, Sustainability Assessment of Food and Agriculture Systems, 17.
} 
Ujang Maman, et al., "Al-Musāqah" And Sharia Agribusiness System...

\section{Sharia Agribusiness System: A Solution}

By the difficulties of Indonesian SFAA formation, and to compliance the FAO-SAFA indicators, sharia agribusiness system (SAS) - in which the al-musāqah is an integrated part of the system - is hoped as proper solution. Referring to the Davis \& Golberg and Soehardjo, Said and Intan categorized agribusiness into two approaches: micro and macro approaches. ${ }^{42}$ The micro is a business in certain agribusiness subsystems which emphasizes on the effectiveness and efficiency. While in the macro perspective, agribusiness is a system consisting the number of sub-systems linked one to another to sustain the national economy. Referring to Said and Intan, ${ }^{43}$ agribusiness at least consist of four subsystems, namely: (1) subsystem of cultivation; (2) distribution and provision of means of production, such as the procurement of fertilizers, seeds, pesticides, and other agricultural inputs; 3) postharvest processing, (4) business administration and marketing, and (5) supporting agribusiness institutions, such as land management, finance, and research. The system is geared to achieve mutually agreed objectives, such illustrations presented in Figure 1.

In the Islamic perspective, the system - which in Arabic is called nizām literally implies the principles of arrangement in which a person thinks and behaves, both regulatory and substantive.44 About word "sharīah," etymologically it has connotation of masyra'ah al-Ma' (source of drinking water). ${ }^{45}$ The Arabic people did not mention the source as shariah, except if the

\footnotetext{
${ }^{42}$ Endang Gumbira Said and Harizt Intan, Manajemen Agribisnis (Jakarta: Ghalia Indonesia, 2011), 23-27.

${ }^{43}$ Ibid., 20-21.

${ }^{44}$ Abbas Mirakhor, "General Characteristics of an Islamic Economic System," in Essay on Iqtisai: Islamic Approach to Economic Problem, ed. Baqir Al-Hasani and Abbas Mirakhor (Silver Spring, USA: Nur Corp, 1989), 54. See also Hafiz Abdurrahman, Islam, Politik Dan Spiritual (Singapore: Lisanul Haq, 1998), 17-18.

${ }^{45}$ Muhammad ibn Mukrim Ibn al-Mandzūr, Lisān Al-'Arab. (Beirut: Dār Ṣādir, n.d.), 175. Muhammad ibn Ya'qūb al-Fayruz al-'Abādī, Al-Qāmūs Al-Muhīț, n.d., 6672. Muhammad ibn Abī Bakr ibn 'Abd al-Qadīr Al-Rāzì, Mukhtār Al-Sịh hà̄t (Beirut: Maktabah Lubnan Nasyīrūn, 1995), 294.
} 
source of water is is plentiful. ${ }^{46}$ In Arabic, syara'a means nahaja (to cover), awdaha (to explain) and bayyana al-masālik (to show the way). Syara'a lahum-yasyra'u-syar'an means sañ̃na (to define ${ }^{47}$ Thereby, sharia has a meaning as the terms and laws established by God Almighty for His servants. Therefore, the sharia agribusiness system (SAS) is a pattern of arrangements about: (a) procurement, distribution, and distribution agricultural input facilities; (b) primary production and aquaculture; (c) business administration and marketing; (d) processing of agricultural products; and (e) arrangements about financial institutions, lending, capital adequacy, and administration of land on the basis of "Islamic law." Borrowing a phrase of Anas Zarqa, the SAS is the impelementation of Islamic values in looking the various of agri sub-systems.48

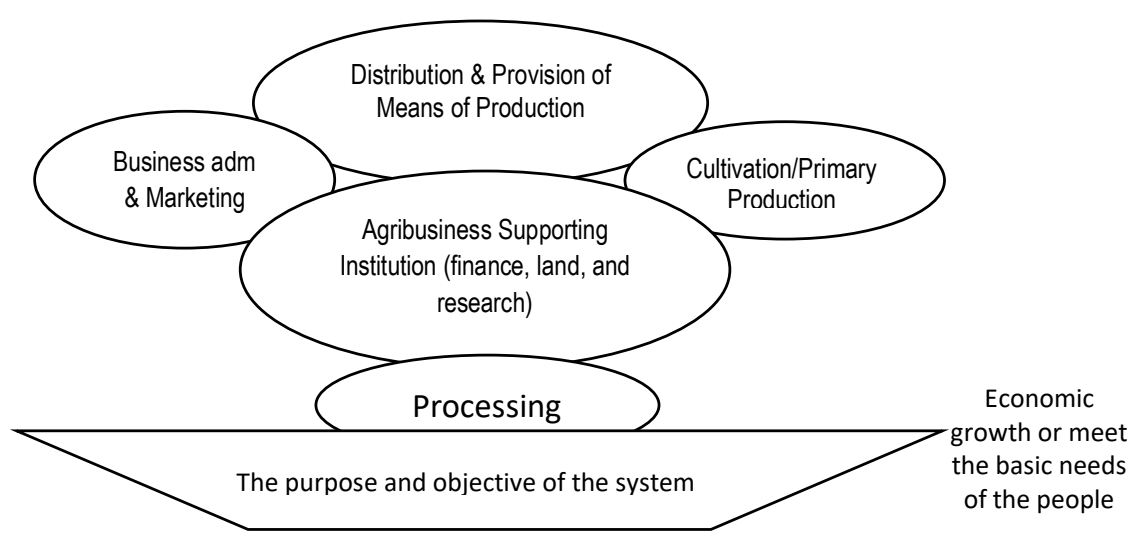

Figure 1. Sharia Agribusiness System

However, the principles of Islam do not regulate the technical issues related to the way of cultivation, primary production and yield processing. Islam does not regulate how to

${ }^{46}$ Ibn al-Mandzūr, Lisān Al-'Arab., 175.

${ }^{47}$ Al-Rāzī, Mukhtār Al-Sihhhāt, 294.

${ }^{48}$ Anas Zarqo, "Islamic Economics: An Approach to Human Welfare," in Reading in the Concept \& Methodology of Islamic Economy: Translating Islamic Principle into Socio-Economics Realities, ed. Aidit Ghazali and Syed Omar (Malaysia: Planduk Publication, 1996), 22. 
increase quality and quantity of products. Islamic civilization heritage shows that Islam opens to a variety of old civilizations that already exist in terms of development of science and technology related to cultivation techniques. In other words, the Muslims during the Islamic golden age studied much various relics of Greek, Roman, Ancient Egypt and Syria in various matters related to the development of agronomy. ${ }^{49}$ The Al-Qur'an motivates people merely to study science and technology to improve quality of human life. For example, Islam calls for quality of food procurement (Q.S. al-Baqarah:168); and encourage the provision of animal husbandry and fishery industry (Q.S. Țāhā: 54 and alMaidah: 96).

By this fact and view, many contemporary Islamic scholars distinguish between madaniyyah and hadārah, as well as between economic science (al-'ulūm al-iqtiṣādì) and the economic system (al-nizām al-iqtiṣādì). Madaniyyah is a result of man's creation in line with the development of civilization and the heights of science and technology, such as producing a wide range of equipment for living. Hadārah is the result of human creations that are in line with their point of view in life and linked, directly or indirectly, to the trust, confidence, and faith. ${ }^{50}$ The economics science is a result of human creation to improve the effectiveness and efficiency of production process of goods and business activities, including registration and administration; while the economic system is more ideological thought that emphasizes on distribution of goods,

\footnotetext{
${ }^{49}$ Many Islamic experts translated books of agronomy, like book of Georgika, the heritage of Bizantium translated into Arabic Language by Sarjis bin Hiliyya Ar-Rumi in the tittle of al-Filaha al-Rumiyya about $212 \mathrm{H} / 827 \mathrm{M}$; Synagoge, the essay of Vindanios Anatolios in the translated article Kitab AlFilaha with the unmentioned translator. See Toufic Fahd, Botany and Agriculture, ed. Roshdi Rashed, Encyclopedia of The History of The Arabic Science: Technology, Alchemy and Life Science (London and New York: Routledge, 1996), 816-817.

${ }^{50}$ Muhammad Husein Abdillah, Al-Dirāāah Fī Al-Fikr Al-Islāmīì (Beirut: Dār al-Bayāriq, 1990), 74-75.
} 
fulfillment of basic needs and complementary needs, and transaction processes that cause switch over of ownership. ${ }^{51}$

In relating with the SAS, there is a sub-system of SAS in the category of economic science, such as sub-systems of cultivation and processing. Similarly, there is a sub system of agribusiness which is categorized in to economic systems, such as procurement, and distribution of production facilities, arrangement of land, partnership pattern between land owners and tenant farmer, setting financial institutions, lending, and capital adequacy. This structuring and arrangements reflect an ideology or at least describe a conviction. The capitalist economic system, for example, puts more emphasis on freedom and individual ownership and rejects government regulation and intervention to get welfare for the people. While the socialist economic system rejects individual ownership and requires government intervention. Islamic economic system recognizes individual ownership, common and the state ownership, and also the way to develop the ownership. ${ }^{52}$

To solve the major problem of SFAA formation, the part of SAS that should be inquired is the way to fulfill the basic human need, particularly staple food, the ownership system, land tenure, SFAA in SAS perspective, and al-musāqah partnership.

\section{The Fulfillment of Basic Needs in Sharia Agribusiness System}

In the basis of ideology, beliefs, and values framework, agribusiness system - as well as the economic system - would have a goal to be achieved. Referring to Said and Intan, agribusiness system aims to improve the gross domestic product (GDP), to increase national income, business opportunities, and decreasing

\footnotetext{
${ }^{51}$ Muhammad Baiquni Shihab, “Antara Sistem Ekonomi Islam Dan Ilmu Ekonomi Islam," 1-6, accessed December 16, 2016, http://steihampara.ac.id/sistem-ekonomi-islam-ilmu-ekonomi-islam.

${ }^{52}$ Baqir Al-Hasani, "The Concept of Iqtisad," in Essay on Iqtisai: Islamic Approach to Economic Problem, ed. Baqir Al-Hasani and Abas Mirakhor (Silver Spring, USA: Nur Corp, 1989), 33-34.
} 
unemployment..$^{53}$ In a macro level of view, based on the common goal of Islamic law, Al-Sirjani asserts that the Islamic Sharia raises a public awareness about the importance of the fulfillment of the economic rights for every citizen. ${ }^{54}$ In line with this idea, Anas Zarqa said that Islamic economic system aims to develop human welfare, with hierarchical indicators. The most basic step is a fulfillment of human necessities; the next is an achievement of conveniences, and the last is a perfection of life, both physical and non-physical wealth, such as religion, thinking ability, and heredity. ${ }^{55}$

In accordance with Zarqa, Chalil divided the human need in the Islamic economic system into three categories which also hierarchical: the need of darüriyyah (basic needs), the needs of hajjiyyah (complementary needs), and the needs of tahsiniyyah (falsifies). ${ }^{56}$ The three hierarchies of needs are both physical and non-physical. The forms of physical basic needs, according Chalil, are: food, clothing, shelter, health and education. While the nonphysical and very essential basic needs is maintenance of religion, life, intellect, lineage, education, and preservation of wealth. ${ }^{57}$ By this view, the procurement and fulfillment of staple food needs in line with the mandate of Indonesian Law No. 18/2012 on Food Regulation, that the food supply is the most fundamental human rights.

${ }^{53}$ Said and Intan, Manajemen Agribisnis, 24.

${ }^{54}$ Rāghib Al-Sirjānī, Mażā Qaddam Al-Muslimūn Li Al-'Ālam Ișāmah AlMuslimīn Fī Al-Hadārah Al-Insāniyyah, ed. Sonif and Mastur Ilham, Indonesian. (Jakarta: Pustaka Al-Kautsar, 2009), 68-69.

${ }^{55}$ Zarqo, "Islamic Economics: An Approach to Human Welfare," 35-36. Monzer Kahf, "Islamic Economic System," in Reading in the Concept \& Methodology of Islamic Economy: Translating Islamic Principle into SocioEconomics Realities, ed. Aidit Ghazal and Syed Omar (Malaysia: Planduk Publication, 1996), 74-75.

${ }^{56}$ Zaki Fuad Chalil, Pemerataan Distribusi Kekayaan Dalam Ekonomi Islam (Jakarta: Erlangga, 2002), 89-103.

${ }^{57}$ Ibid., $93-132$. 
The achievement targets of the economic system require the existence of rules and the Government as implementing agencies. In this case, government has a very big role to achieve these objectives. Relevant with this view, Mirakhor asserted that the government and the country is a two basic institutions, the responsible, and as the main engine implementer of the shariabased system..$^{58}$ However, Mirakhor also recognized the role of members and leaders of a community. In line with this, Ibn Ibrahim asserted that the policy in a system geared to meet the needs of individuals and the needs of the group. The individual needs divided into two main categories, namely the fulfillment of basic needs (primary) and support needs (secondary and tertiary).The fulfillment of basic needs is a government obligation; while fulfilling the secondary and tertiary needs is not a government obligation, but the government should make a condition that every people has the opportunity to meet the secondary and tertiary needs, ${ }^{59}$ as illustrated in Figure 2.

On basis of such a case, the SAS to fulfill staple food is difference with the SAS to meet secondary and tertiary needs, such as the cultivation of cocoa, coffee, and tobacco. To fulfill the basic needs, the government is obliged to: (a) provide the land in a proportion of the amount of rice needs; (b) provide rice production means and do a control strictly in order to get to the farmers; (c) control the distribution in delivering goods in order to get really to people who need it; (d) improve skills of farmers in terms of cultivation, harvesting, and processing, (e) provide adequate budget; and (f) strengthen the farmer institution.

In providing the basic needs for the people, business law and market mechanism should not be applied, but it is fully controlled by government. However, for the SAS that aims to meet the

\footnotetext{
${ }^{58}$ Mirakhor, "General Characteristics of an Islamic Economic System," 73.

${ }^{59}$ Abdurrahman Al-Maliki, Al-Siyāsah Al-Iqtișādiyyah Al-Mustla, ed. trans. Ibnu Sholah, Indonesian. (Bangil: al-Izzah, 2001), 45.
} 
secondary and tertiary needs, the Government should release it on market mechanism. Therefore, for the second category of SAS, the law of business and market mechanism should be applied, in which the determination of prices is entirely submitted to the market mechanism; and a person has the right to do a business and take advantage from the fulfillment activities in the field of secondary and tertiary needs. However, the Government is obliged to control in order to prevent fraud, deception, stacking (distortion of the market), and avoid the possibility of unfair competition.

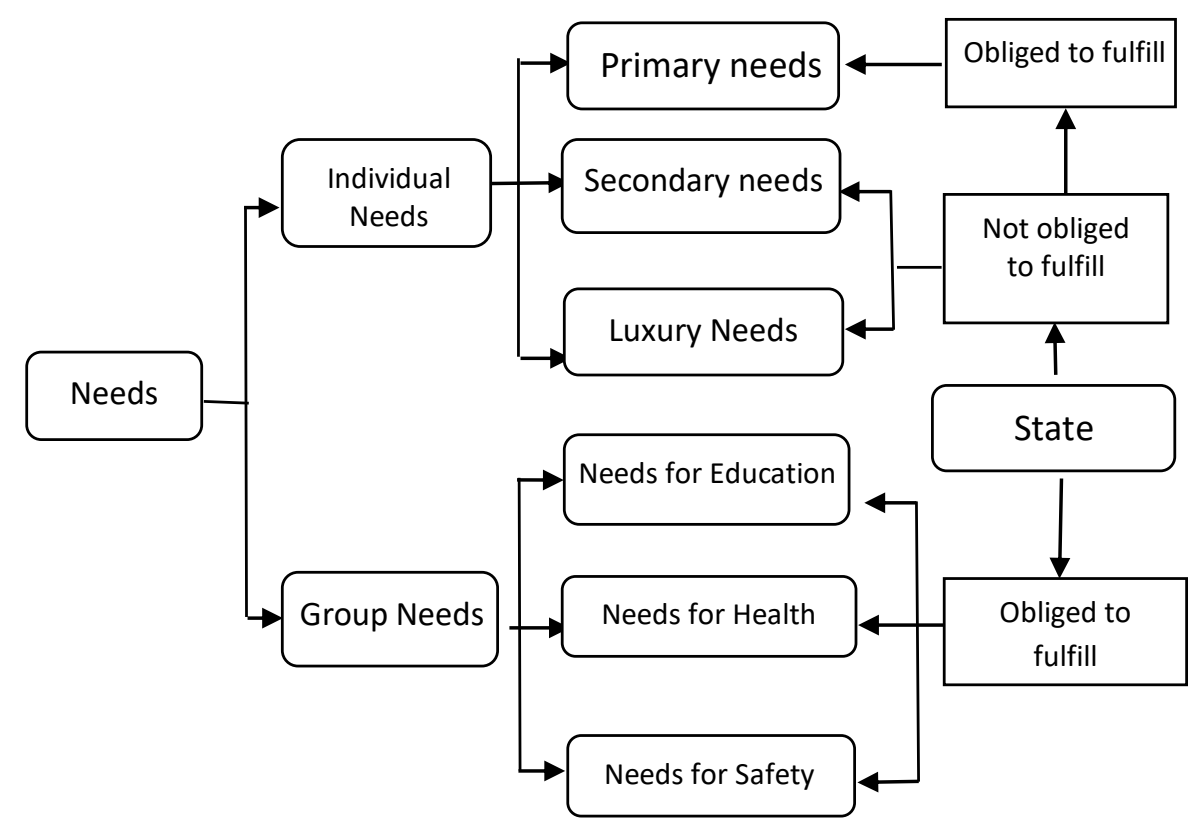

Figure 2. Illustration of Basic Needs Fulfillment Policy

By the presence of the state as the main responsible for food basic need's procurement and fulfillment, it does not mean that it is entirely the responsibility of the state. Based on the people's consciousness, they may play a role in food procurement. It is based on the general proposition that every people, especially heads of households are obliged to work and meet the basic needs for their families. By the presence of the government as the main 
responsible for food procurement, the farmer households will not get burdened to provide food at a low price for other parties. Elaboration of food fulfillment will lead to the management system and land control (land tenure) in agribusiness sharia perspective.

\section{The Ownership Concept in Sharia Agribusiness System}

In SAS, the ownership concept is very important. The awareness of the ownership is very essential for a policy and behavior, both for consumers and producers. According to Islamic conception, all the wealth in the universe is essentially belongs to Allah, so that someone in developing properties must be in accordance with God's rule. This is a contrast with the capitalist conception of ownership who stressed that the highest owner is an individual, so that the will of individual should be a major determinant..$^{60}$

In the perspective of whom has the right to manage assets, natural resources and wealth contained in a country, it could be grouped into three categories: individual, public and state. This description refers to a number of hadiths. Among them is a hadith told about Abyadl bin Hamal Al-Mazini who came to Prophet and asked the right to mine salt. The Prophet gave it. But when the Prophet received information that the salt is a mineral that is needed by all people and the source is unlimited, the Prophet withdraw the rights granted to Abyadl. ${ }^{61}$ Here is another hadith in which the Prophet affirmed that human is associated in three properties: water, fire, and grasslands. Also another hadith confirms the prohibition for individual to control some objects that are needed by many people and the source is unlimited. From here, Husein Abdillah classified the ownership into three categories: individual, common and state ownership.

\footnotetext{
${ }^{60}$ Kahf, "Islamic Economic System," 76. Zarqo, "Islamic Economics: An Approach to Human Welfare," 32.

${ }^{61}$ Muhammad Husein Abdillah, Al-Dirāsah Fī Al-Fikr Al-Islāmī, 54-55.
} 
Individual ownership has a function of productivity, business development, and economic growth. For private property, it should be applied economic law, such as perfect competition, market mechanisms, profit achievement, and efficiency. Islamic values teach someone to constantly develop his property. However, in the transaction should apply various sharia provisions, like prohibition of usurious transactions, fraud, deception, and stockpiling to distort market. ${ }^{62}$ However, the individual ownership contained elements of public interest, such as donation to establish educational institutions, build mosques, etc. ${ }^{63}$

Common ownership in Islamic value has a function to support the development of individual ownership. Conceptually, Islam prohibits the privatization of public ownership, such as minerals, water which becomes a common need, energy, and forest wealth. Instead, the state should manage it, but the government should not take advantage but merely the cost of production. The state restores everything to the people. Therefore, in general, it should not apply market mechanism and business approaches in managing the public ownership.

Beside the two concepts of ownership, Islam recognizes the state property. The state can use all of the asset for a variety of activities that lead to the welfare of the people and the sustainable of the state, such as providing of basic needs (both for of individual and groups need) include food providing, warehouse which is necessary for storage and distribution of food, hospitals, and education; the industry for defense and other strategic industries for provision of basic needs, including the cost for the necessary research. In this case there is a process of mutual interaction to support the common ownership of property.

\footnotetext{
${ }^{62}$ Ibid., 189-201.

${ }^{63}$ Ḥusein Ḥamīd Maḥmūd, Al-Nìzām Al-Māl Wa Al-Iqtiṣādī Fī Al-Islām (Riyadh: Dār al-Nasyrī al-Daulī, 2000), 228-229.
} 
The differences between common and state ownership is that the public ownership properties may not be privatized which are left to the individual or group of the people as private companies. While the state ownership, both movable and immovable property, is entirely controlled by the state. In managing the property, it depends on the Government policy for welfare of the people, both are given to individuals (for housing), as well as managed by the state such as protected areas, urban forests, catchment areas, etc. The Government could change the land entitlement from state or public owned land to the individual or public interest. ${ }^{64}$

\section{Land Tenure in Sharia Agribusiness System: Al-musāqah}

In agricultural sociology, there is a concept of land distribution (LD) and land tenure (LT). LD refers to distribution of agricultural land ownership; while LT refers to the right of land use. The LT and LD are two determinant factors to form of agrifood structure. ${ }^{65}$ Referring to Smith and Zop, LT is the "Rights of a person on the land, namely the legal right to use, process, sell, and take advantage of certain parts of land surface. ${ }^{66}$ If LT emphasizes on the right of land use, LD stresses on the area of land owned by family, state, or employers.

On the basis of LT and LD, Kuhren identifies the structure of food crop in many parts of the world. Among them is family, capitalistic and socialistic agriculture. ${ }^{67}$ Prominent feature of family farm, according to Kuhren, is the property and land use rights are in the hands of family. The consequence, the family who owns land is responsible to manage the land. In a capitalistic

\footnotetext{
${ }^{64}$ Rummana khan Sherwani and Muhammad Asim, "Land Management through the Advent of Islam," Journal of Islamic Thought and Civilization 5, no. 1 (2015): 1-12.

${ }^{65}$ Rahardjo, Pengantar Sosiologi Pedesaan dan Pertanian, 147.

${ }^{66}$ Quoted from Ibid., 136.

${ }^{67}$ Frithjof Kuhren, "Man and Land: An Introduction into the Problems of Agrarian Structure and Agrarian Reform," in Agricultural Sociology, ed. Ultrich Planck, Indonesian. (Jakarta: Yayasan Obor Indonesia, 1990), 20-25.
} 
agriculture, property and management rights of agricultural land are in the hands of entrepreneurs. In contrast, in the socialistic agriculture, the ownership and management of land are in the hands of the collective community.

In perspective of SAS, LT could be categorized into two parts, individual and state property. The decisiveness concept of land ownership is essential for the development and establishment of agricultural policy, because the existence of the land is very essential for agricultural production. ${ }^{68}$ At the period of Prophet, there was an arable fay'iland (state owned land) located in Khaibar area, which include: As-Syiqq, Nathah, Al-Katibah, and Fadak. The land was originally belonged to Jews, then abandoned by the owner who fled after they defeated in Battle of Khaibar in the seventh of Hijri. ${ }^{69}$ The battle of Khaibar came after Jewish groups of Medina conspiring with Quraysh to destroy Medina in the Battle of Ahzab. ${ }^{70}$ The Prophet distributed the land area of As-Syiqq, Nathah, and AlKatibah into eighteen sections and each section consisted of one hundred parts, which is directly given to the muslim army and people, while the Prophet got merely one fifth (20\%) of the land as a state owned land..$^{71}$ While, for Fadaq which is also around Khaibar, in which it is conquered without any war, the land was totally

${ }^{68}$ Abdurrahman Al-Maliki, Al-Siyāsah Al-Iqtișādiyyah .., 45.

${ }^{69}$ Ibn Hisyam, Sìrah Nabawiyyah Ibn Hisyām, 307.

${ }^{70}$ Fūrī, Al-Rahīq Al-Makhtūm.

${ }^{71}$ The șahabah of Muhammad who got the part of land from three areas of al-Syiqq, Nathah, and Al-Katibah is Ali bin Abi Thalib, Az-Zubair bin alAwwam, Thalhah bin Ubaidillah, Umar bin al-Khaththab, Abdurrahman bin Auf, Ashim bin Adhi from Bany Al-Aljan, Usaid bin Al-Hushair, Al-Harits bin alKhazraj, Na'im, Bani Bayadhah, Bani Ubaidah, Bani Hara, from Bani Salimah, Ubaid bin As-Shiham, Saidah, Gifar and Aslam, An-Najjar, Haritsah and Aus. Each of them got one hundred parts for their community. So, the areas of Khaibar divided into one thousand and eight hundred parts. See Ibn Hisyam, Sirah Nabawiyyah Ibn Hisyām, 321-322. 
controlled by The Prophet as a state owned land. ${ }^{72}$ Therefore, the majority of Khaibar Land became state owned land (fay'iland). ${ }^{73}$

To maintain food-agri land of Khaibar, the Prophet employed a number of Jews as tenant, based on the agreement that Jews received half of land yield. To get the exact number of date yielded from the Khaibar, the Prophet appointed Abdullah bin Rawahah as controller. After passing away in Mu'tah battle, the position of Ibnu Rowahah was replaced by Jabbar bin Shakhr bin Umaiyyah bin Khansa. ${ }^{74}$ The tenure agreement between The Prophet and Jews had lasted until the coming of Umar bin Khaththab's administration. For the beginning, Umar recognized and executed the agreement, but based on the Prophet testament in his deathbed - in which he ordered the prohibition of two religions merging in Arabian Peninsula between Islam and other religion -Umar eliminated the tenure agreement. ${ }^{75}$

The historical event of Khaibar indeed has brought out the deliberation of al-musāqah in fiqh studies. ${ }^{76}$ The definition of almusāqah-in fiqh terminology-is a partnership between land owners and tenant farmers to maintain the grown and productive trees or the existed trees, in which the tenants get a half of agricultural yield based on agreement between both parties. ${ }^{77}$ If the partnership is started from land clearing, land cultivation, and seed growing, in which the farmer does not get any benefit or salary beside the agreement of yield sharing, such as 50:50 or 30:70 or other agreement, the concept is not al-musāqah, but shifted to

${ }^{72}$ Ibid., 325.

${ }^{73}$ Maḥmūd, Al-Nịāām Al-Māl Wa Al-Iqtiṣādī Fī Al-Islām, 192.

${ }^{74}$ Ibn Hisyam, Sìrah Nabawiyyah Ibn Hisyām, 326.

${ }^{75}$ Ibid., 328-329.

${ }^{76}$ Imam Abī Ishāq Ibrāhīm Ibn 'Ālī, Al-Muhažzab Fī Fiqh Al-Imām AlSyāfi' '̄, Vol. I. (Beirut: Dār al-Fikr, n.d.), 390-391.

${ }^{77}$ Al-Baghdādī, Hukm Al-Islām Fi Ijārat Al-Ard Li Al-Zirāàh, Hukm AlIslām Fī Māl Al-Ghulul Min Al-Hukkām Wa Muwāzif Al-Daulah, Ma'âyir Al-Ațwāl Wa Al-Misahat Wa Al-Akyāl Wa Al-Auzān Al-Syariyyah, Indonesia. (Bandung: alMa'arif, 1987), 32. 
other concept which is popular in fiqh deliberation as al-muzaroah if the all input productions are from the land owner. It is well known, that the kind of practice is prohibited according to fiqh scholar. If somebody performs the same practice, but the input production, like seed, pesticide, and production device, is entirely from the tenant farmer, the practice is called al-mukhobaroh which strongly prohibited in fiqh deliberation. ${ }^{78}$

Logically, as the agriculture is a high risk practice of plant's disease and pest attack, the tenant farmer in mukhobaroh practice will get the highest risk because the plant has not been growing, and the farmer will get probably facing loss of time, man power, and capital if the risk really happen; while the land owner does not face the risk at all. Based on the fact, the mukhobaroh partnership is strongly prohibited. The risk will get decrease in muzaroah practice, but still high, and the farmer will probably loss time and man power only; and the land owner get the zero risk. The fact leads us to get bright that the practice is prohibited. The almusāqah partnership is really in contrary. As the plant has been growing, the risk of tenant gets slight. If the risk happens, the tenant farmer merely gets loss of time and man power, and the land owner losses capital. To minimize the risk of al-musāqah, it should be clear about partnership period, kind of work that should be done by the tenant farmer, and also should be clear about the sharing ratio of agricultural commodity yield. For the side of the farmer, he should be trustworthy and have a strong commitment to grow and maintain the plant. ${ }^{79}$

In the case of Khaibar, the land owner in al-musāqah partnership is a state, in which it was represented by the Prophet as the head of the state. Relating to the fact of history, in fiqh deliberation, based on the general meaning of al-musāqah, the land

${ }^{78}$ Al-Malebary, Fatḥ Al-Mu'īn Bi Syarh Qurrah Al-'Ain, 82-88. See also Ibn 'Ālì, Al-Muhaẓ̌ab Fì Fiqh Al-Imām Al-Syāfi' '̄', 393-394.

${ }^{79}$ Ibid., 392-393. 
owner could probably an individual or private sector as well as the state. The further discussion about the meaning of al-musāqah, it should be refer to fiqh deliberation out of this context.

\section{The Formation of SFAA in the Sharia Agribusiness System: A Conceptual Framework}

In the historical event of Khaibar, the Prophet distributed the land to the army and muslim society, but the Prophet also preserved the majority of land as state ownership, and he allocated specially for center area of date procurement. The Umar's administration, in line with the Prophet policy, completed the distribution of Wad al-Qurro in Khaibar area to muslim society, ${ }^{80}$ but he also hold as-Sawad-- an arable land along the river basin of Tigris and Euphrates in Iraqi zone after defeating the Persian Kingdom -- as a state owned land, and designated for food-agri center. ${ }^{81}$ By the fact, the staple food procurement in SAS perspective is mainly a state responsibility. Of course, the land procurement for staple food supply is not charged solely to the individual farmers but to the state-owned land. The individual land is merely a complementary as illustrated in Figure 3.

Relevant with the concept, many individual land owners in the Prophet era handed their land over as a "waqf land" for purpose of food providing. This food plantation is well known in Islamic history as hawaith, that is a land intended specially for food product plantations. Among hawaith dedicated for food procurement and known by the name of the donors are the hawaith of Mukhairiq, which is consisted of seven gardens, and hawaith of Abu Dahdah..$^{82}$ However, it should be realized that the individual has a complete freedom to manage their ownership of

\footnotetext{
${ }^{80}$ Ibn Hisyam, Sīrah Nabawiyyah Ibn Hisyām, 329-340.

${ }^{81}$ Robert C. Allen and Leander Heldring, The Collapse of the World's Oldest Civilization: The Political Economy of Hydraulic State and Financial Crisis of Abbasid Caliphate (Abu Dhabi, 2016), 3-4.

${ }^{82} \mathrm{Hafidz}$ Ahmad 'Ajjaj Al-Karmi, Al-Idāroh Fī Așhr Al-Rasulillāh Șallallāhu Alaih Wa Sallam, Indonesian. (Bogor: Pustaka Thoriqul Izzah, 2012), 256.
} 
land, both for food crops or other uses according to each choice. By the fact of history, in the Islamic conception, the government should not force the private land owners to provide staple food for citizens from their land.

As mentioned above, in the SAS perspective, the main land for staple food provision should be the state owned land. In figh discussion, the state owned land is as following. First, the all types of dead and neglected lands, either deserts, mountains, hills, valleys, beaches, land that has not been planted, or the land which once was planted but later is abandoned, because it had not been taken care by the owners. Second the land which is covered by soil sediment or covered by water, in which the land is unfeasible to agricultural uses. In this case, the state could re-create the land for agricultural purposes such as reclamation. ${ }^{83}$ In this case, the state could allocate budget to re-functionalize the land. Moreover, the state owned land can be derived from individual land purchased by state for the benefit of staple food supply.

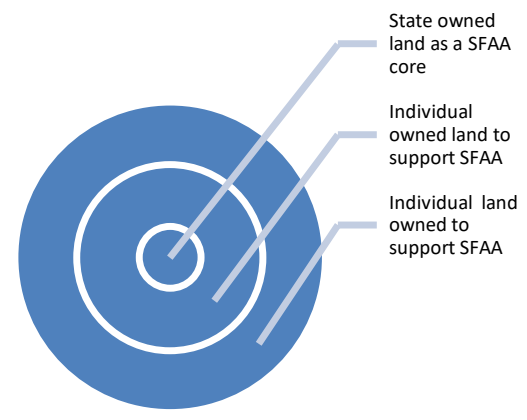

Figure 3. Ilustration of SFAA Formation in SAS

In addition, the lesson that might be learnt from the history of Khaibar was that the Prophet did not merely provide the particular land for staple food supply, but he also controlled tightly the staple food supply chain process and distribution. By the fact

\footnotetext{
${ }^{83}$ For further discussion, can refer to Sherwani and Asim, "Land Management through the Advent of Islam," 1-12. and Al-Maliki, Al-Siyāsah AlIqtișādiyyah Al-Mustla, 195-199.
} 
noted in the sirah nabawiyyah as a legal source of the Muhammad's policy and behavior indicated clearly that the Prophet distributed the dates, cereals, wheat, and nuts yielded from protected agricultural area of Khaibar directly to individual citizen in accordance with their needs. The popular passage of history that came to contemporary time told that each individual society in Madinah who participated in Hudaibiyyah treaty and in Khaibar battle got certain allocation of Khaibar yields. For example, the family of Usamah bin Zaid obtained 200 wasaqs; Aqil bin Abu Thalib acquired 140 wasaqs, the sons of Ja'far got 50 wasaqs, Rabiah bin Al-Harits got 100 wasaqs, As-Shalt bin Markhamah and his two sons got 100 wasaqs, Qais bin Markhamah got 30 wasaqs, Abu Al-Qasim bin Markhamah gained 40 wasaqs, and other individual got each parts. ${ }^{84}$ It should probably be noted that the "wasaq" is a popular traditional measurement of weight in ancient Arabic society, especially in fiqh expression, that every wasaq consisted of 130.56 $\mathrm{kg} .{ }^{85}$

The Prophet surveillance of staple food allocation did not stop until the mentioned above action. In his bed death, the Prophet told his testaments in which he ordered that the group of Rahawiyyīn community, Al-Dāriyyīn, Al-Shubaiyyīn, as well as AlAshariyyīn people, each of them should get 100 wasaqs of Khaibar wheat. ${ }^{86}$ This testament was authentically recognized by Umar bin Khaththab, in which he obeyed the order. ${ }^{87}$

\section{The al-musāqah and Management of SFAA}

The above discussion of SAS, particularly about basic need fulfillment, land ownership and land tenure in Islamic perspective, and finally proved by the fact of Khaibar event, it actually had

\footnotetext{
${ }^{84}$ Ibn Hisyam, Sīrah Nabawiyyah Ibn Hisyām, 323.

${ }^{85}$ Al-Baghdādī, Hukm Al-Islām Fi Ijārat Al-Arḍ Li Al-Zirāàh, Hukm AlIslām Fī Māl Al-Ghulul Min Al-Hukkām Wa Muwāzif Al-Daulah, Ma'āyir Al-Ațwāl Wa Al-Misahat Wa Al-Akyāl Wa Al-Auzān Al-Syariyyah, 92.

${ }^{86}$ Ibn Hisyam, Sirrah Nabawiyyah Ibn Hisyām, 324.

${ }^{87}$ Ibid., 328-329
} 
paved the clear way to form the Sustainable Food Agricultural Area (SFAA) which should not be converted into other uses beside staple food provision.

In the context of recent Indonesia, the formation of SFAA gets high complexity problems, and directly causes the existence of Sustainable Food Agricultural Land Protection (SFAL-P) Act is ineffective because of the absence of clear land that should be dedicated for SFAA purposes. The farmer, of course, shows their resistance to the policy doe to its contradiction to the basic human right of their ownership. For the farmer, the land is commonly a basic asset for their life; and logically in a polite and people oriented policy, the Government should let them to manage their high valuable asset according to their own will.

Based on the SAS's basic principle - which expected as a proper solution - to establish SFAA, it should identify the state owned land, or the land which could potentially be entirely controlled by the central as well the local government. It is the first step to perform. For Indonesian condition, the step is not strongly difficult. According to Ministry of Agriculture (MoA) data, until the end of 2012 there were 11,949,727.00 ha of mooring land area, ${ }^{88}$ scattered throughout the Indonesian provinces and districts. In addition, according to the same source in Indonesia until the year 2012 there were still unused land area of 14,252,383ha, which was spread all over Indonesia. ${ }^{89}$ of course, the lands can be designated as SFAA with gradual cultivation according to availability of budget and the priority of yearly rice procurement. This is actually in line with the MoA's policy to create new paddy wetland, ${ }^{90}$ and it is expected to meet the sustaining criteria mandated by SFAL-P Act.

\footnotetext{
${ }^{88}$ Center for Agricultural Data and Information System, Statistics of Agricultural Land 2008-2012, 114.

${ }^{89}$ Ibid., 187

${ }^{90}$ Kementerian Pertanian, Mencetak Sawah Baru Di Indonesia (Jakarta: Direktorat Jenderal Prasarana dan Fasilitas Pertanian, 2013), 6-8.
} 
Making the paddy wetland is the second step. But, the stage is, indeed, incomplete unless it is followed by formatting the organizational structure of SFAA, as a third step of the process. The structure of SFAA should cover the entire regions of Indonesia, from the central to local area, as illustrated in Figure 4 . The organization of SFAA could be in the form of state owned enterprise. The fourth step is to describe the detail functions of SFAA, in which it is to manage the yield of rice product, to control tightly the staple food distribution, to make partnership with the farmers gather in farmer group, to monitor the number of rice products from each region of Indonesia, to count the sufficiency and deficiency the number of rice in harvest period to meet the need of the citizens. By the detail functions, the Government will get easily to implement the proper policy toward food selfsufficiency.

The partnership pattern should be outlined in al-musāqah concept, in which the input production, and the fund for making the new paddy wetland is entirely from the SFAA organization as Government institution; and the farmer dedicates manpower, time, and skill in which part of the yield is for them. This pattern of partnership is not merely based on SAS compliance, but also based on the fact that the pattern will directly bring out the implication for farmer empowerment and make a chance of work for the people. To support the successful of SFAA and al-musāqah partnership, the institution has a complementary task to educate the farmer, disseminate innovation, and fertilize the high achievement motivation of the farmer. Finally, as the fifth stage, the SFAA organization should be equipped by information system and technology to get easily to meet food self-sufficiency. 


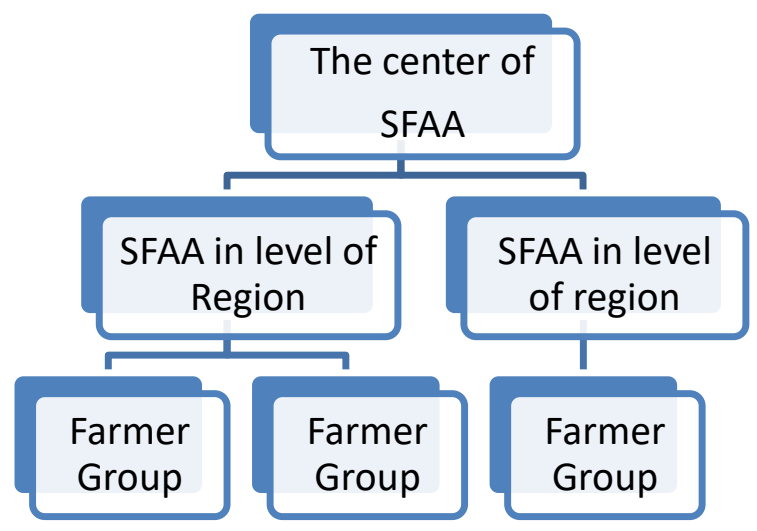

Figure 4. The Illustration of SFAA Organization

However, this subject of study, particularly the formation of SAFA institution, the organization structure needs a further discussion about budget, period, pilot project, and the readiness of the central and local government, and many other technical considerations. But, the importance matter in this study is to pace making of the food policy on the right track.

\section{Conclusion and Implication}

In the light of literature study and considering the facts, the discussion finally comes to conclusion as following:

1) The SAS for procurement of secondary and tertiary needs is left entirely to the market mechanism, in which it imposes market balance and applies the business law. The government oversees merely in order to avoid conflict, fraud, deception, and unfair competition. However, the SAS to procure the basic need, particularly the staple food, should be directly managed and controlled by the Government in yielding the product as well as in distributing to the people in accordance with their needs.

2) The SFAA formation is not on the individual owned land, but it should be in state owned land, and fully financed, managed and controlled by a government in which it is represented by the 
SFAA institution and it is most likely as state owned enterprises. The individual owned land is merely a complementary in SFAA establishment; and the consequence, it leads to the absence of paddy wetland conversion, potential conflict and the loose of the farmers.

3) The SFAA institution should cover the entire region of Indonesia, the central as well as the local Government, and it implemented the al-musāqah pattern of partnership in which it benefitted the empowerment of the tenant farmer and the jobless people.

By the conclusion, the study will lead to the implication, in which it gets to develop the kind of Islamic study based on the empirical facts, involving the real issues of society, and directly or indirectly lead to solve the problem. The study also brings special input to the government policy, particularly toward food selfsufficiency, extend the chance of work, decreasing the scarcity of work chance in rural society; and of course this kind of study will get coloring the type of Islamic studies.

\section{References}

'Abādī al-, Muḥammad ibn Ya'qūb al-Fayruz. Al-Qāmūs Al-Muhịt, n.d.

Abdillah, Muḥammad Husein. Al-Dirāsah Fĩ Al-Fikr Al-Islāmī. Beirut: Dār al-Bayāriq, 1990.

Abdurrahman, Hafiz. Islam, Politik Dan Spiritual. Singapore: Lisanul Haq, 1998.

Allen, Robert C., and Leander Heldring. The Collapse of the World's Oldest Civilization: The Political Economy of Hydraulic State and Financial Crisis of Abbasid Caliphate. Abu Dhabi, 2016.

Apriyana, Nana. Kebijakan Pengendalian Konversi Lahan Pertanian Dalam Rangka Mempertahankan Ketahanan Pangan Nasional. Jakarta: Kementerian Perencanaan Pembangunan, 
Ujang Maman, et al., "Al-Musāqah" And Sharia Agribusiness System...

2011.

Asmara, Andi. "Pendapatan Petan Setelah Konversi Lahan: Studi Kasus Kelurahan Mekarwangi, Kota Bogor." Universitas Islam Negeri Syarif Hidayatullah Jakarta, 2011.

Baghdādī al-. Hukm Al-Islām Fi Ijārat Al-Arḍ Li Al-Zirāàh, Hukm AlIslām Fĩ Māl Al-Ghulul Min Al-Hukkām Wa Muwāzif AlDaulah, Ma'àyir Al-Ațwāl Wa Al-Misahat Wa Al-Akyāl Wa AlAuzān Al-Syariyyah. Indonesia. Bandung: al-Ma'arif, 1987.

Barakah, Ummu. Dampak Konversi Lahan Pertanian Terhadap Pendapatan Rumah Tangga Petani Di Kabupaten Karanganyar. Solo, 2012.

Center for Agricultural Data and Information System. Statistics of Agricultural Land 2008-2012. Jakarta: MoA, 2013.

Chalil, Zaki Fuad. Pemerataan Distribusi Kekayaan Dalam Ekonomi Islam. Jakarta: Erlangga, 2002.

Dwipradnyana, I Made Mahadi. "Faktor-Faktor Yang Mempengaruhi Konversi Lahan Pertanian Dan Pengaruhnya Bagi Kesejahteraan Petani: Studi Kasus Di Subak Jadi, Kediri, Tabanan." Udayana University, 2014.

Fahd, Toufic. Botany and Agriculture. Edited by Roshdi Rashed. Encyclopedia of The History of The Arabic Science: Technology, Alchemy and Life Science. London and New York: Routledge, 1996.

FAO, IFAD and WFP. The State of Food Insecurity in the World: Strengthening the Enabling Environment for Food Security and Nutrition. Rome: FAO, 2014.

FAO. Sustainability Assessment of Food and Agriculture Systems. Rome: FAO, 2012.

Fujimoto, Akmi. "Rice Land Ownership And Tenacy System in South East Asia: Facts and Issues Based on The Village 
Studies." The Developing Economies XXQUOTEDXI, no. 3 September (1996).

Fūrī, Syaikh Syafiyyah al-Raḥmān al-Mubārak. Al-Raḥīq AlMakhtūm. Riyadh: Muassasah al-Ṡaqāfah, 2012.

Garcia, Manuel B. Sociology of Development: Perspective and Issues. Manila: National Book Store, 1985.

Handari, M.F. Anita Widhy. "Implementasi Kebijakan Lahan Pertanian Pangan Berkelanjutan Di Kabupaten Magelang." Universitas Diponegoro Semarang, 2012.

Hasani al-, Baqir. "The Concept of Iqtisad." In Essay on Iqtisai: Islamic Approach to Economic Problem, edited by Baqir AlHasani and Abas Mirakhor. Silver Spring, USA: Nur Corp, 1989.

Holsti, Ole R. Content Analysis for The Social Sciences and Humanity. Califonia: Addison-Wesley Publishing Company, 1969.

Ibn ‘Ālī, Imam Ab̄̄ Ishāq Ibrāhīm. Al-Muhazzab Fī Fiqh Al-Imām AlSyāfi' 'î. Vol. I. Beirut: Dār al-Fikr, n.d.

Ibn al-Mandzūr, Muhammad ibn Mukrim. Lisān Al-'Arab. Beirut: Dār Șādir, n.d.

Ibn Hisyam, Abū Muḥammad Abū al-Mālik al-Muafirī. Sīrah Nabawiyyah Ibn Hisyām. Jakarta: Darul Falah, 2003.

Irawan, Bambang. "Konversi Lahan Sawah: Potensi Dampak, Pola Pemanfaatannya, Dan Faktor Determinan." Forum Penelitian Agro Ekonomi 23, no. 1 (2005): 1-18.

Jati, Kumara. "Staple Food Balance Sheet, Coefficient of Variation, and Price Disparity in Indonesia." Journal of Advanced Management Science 2, no. 1 March (2014): 65-71.

Kahf, Monzer. "Islamic Economic System." In Reading in the Concept \& Methodology of Islamic Economy: Translating 
Ujang Maman, et al., "Al-Musāqah" And Sharia Agribusiness System...

Islamic Principle into Socio-Economics Realities, edited by Aidit Ghazal and Syed Omar. Malaysia: Planduk Publication, 1996.

Kalof. Essential of Social Research. New York: Open University Press, 2008.

Karmi al-, Hafidz Ahmad 'Ajjaj. Al-Idāroh Fī Așhr Al-Rasulillāh Sallallāhu Alaih Wa Sallam. Indonesian. Bogor: Pustaka Thoriqul Izzah, 2012.

Kementerian Pertanian. Mencetak Sawah Baru Di Indonesia. Jakarta: Direktorat Jenderal Prasarana dan Fasilitas Pertanian, 2013.

Krisnamurthi, Bayu. "Revitalisasi Pertanian: Sebuah Konsekuensi Sejarah Dan Tuntutan Masa Depan." In Revitalisasi Pertanian Dan Dialog Peradaban, edited by Bayu Krisnamurthi. Jakarta: Kompas, 2006.

Kuhren, Frithjof. "Man and Land: An Introduction into the Problems of Agrarian Structure and Agrarian Reform." In Agricultural Sociology, edited by Ultrich Planck. Indonesian. Jakarta: Yayasan Obor Indonesia, 1990.

Maḥmūd, Ḥusein Ḥamīd. Al-Niẓām Al-Māl Wa Al-Iqtiṣādī Fī AlIslām. Riyadh: Dār al-Nasyrī al-Daulī, 2000.

Malebary al-, Zainuddin. Fatḥ Al-Mu'in Bi Syarh Qurrah Al-'Ain, n.d.

Maliki al-, Abdurrahman. Al-Siyāsah Al-Iqtiṣādiyyah Al-Mustla. Edited by trans. Ibnu Sholah. Indonesian. Bangil: al-Izzah, 2001.

Mirakhor, Abbas. "General Characteristics of an Islamic Economic System." In Essay on Iqtisai: Islamic Approach to Economic Problem, edited by Baqir Al-Hasani and Abbas Mirakhor. Silver Spring, USA: Nur Corp, 1989. 
Muhajir, Noeng. Metodologi Penelitian Kualitatif. Yogyakarta: Rake Sarasin, 2000.

Nabangchang, Orapan, and Eathipol Srisawalak. Good Governance And Natural Resources Tenure In South East Asia Region. Rome: Food And Agriculture Organization of The United Nations, 2008.

National Development Planning Board. Analysis of Household, Land, and Agribusiness in Indonesia: Agricultural Census 2013. Jakarta: NDPB, 2014.

Neef, Andreas. "Land Tenure and Soil Conservation Practices: Evidence from South Africa and South East Asia." In Sustaining the Global Farm (Selected Paper from the 10th International Soil Conservation Organization Meeting, edited by D.E. Stott, R.H. Mohtar, and G.C. Steindhardt. Purdue University and USDA-ARS National Soil Erosion Research Laboratory, 1999.

Neuman, Lawrence W. Social Research Methods: Qualitative and Quantitative Approaches. Boston: Allyn and Bacon, 1994.

Rahardjo. Pengantar Sosiologi Pedesaan Dan Pertanian. Yogyakarta: Gadjah Mada University Press, 1999.

Rāzī al-, Muhammad ibn Abī Bakr ibn 'Abd al-Qadīr. Mukhtār AlSihhāt. Beirut: Maktabah Lubnan Nasyīrūn, 1995.

Sabiq, Sayyid. Fiqh Sunnah. Indonesian. Bandung: Pustaka, 1993.

Said, Endang Gumbira, and Harizt Intan. Manajemen Agribisnis. Jakarta: Ghalia Indonesia, 2011.

Sherwani, Rummana khan, and Muhammad Asim. "Land Management through the Advent of Islam." Journal of Islamic Thought and Civilization 5, no. 1 (2015): 1-12.

Shihab, Muhammad Baiquni. "Antara Sistem Ekonomi Islam Dan Ilmu Ekonomi Islam.” Accessed December 16, 2016. 
Ujang Maman, et al., "Al-Musāqah" And Sharia Agribusiness System...

http://steihampara.ac.id/sistem-ekonomi-islam-ilmuekonomi-islam.

Sirjānī al-, Rāghib. Mażā Qaddam Al-Muslimūn Li Al-'Ālam Ișāmah Al-Muslimīn Fī Al-Haḍārah Al-Insāniyyah. Edited by Sonif and Mastur Ilham. Indonesian. Jakarta: Pustaka Al-Kautsar, 2009.

Susilowati, Sri Hery, and Mohamad Maulana. "Luas Lahan Usahatani Dan Kesejahteraan Petani: Eksistensi Petani Gurem Dan Urgensi Kebijakan Reforma Agraria." Analisis Kebijakan Pertanian 10, no. 1 (2012): 17-30.

Zarqo, Anas. "Islamic Economics: An Approach to Human Welfare." In Reading in the Concept \& Methodology of Islamic Economy: Translating Islamic Principle into Socio-Economics Realities, edited by Aidit Ghazali and Syed Omar. Malaysia: Planduk Publication, 1996. 
Vol. 14, Number 2, December 2017: 189-231 